\title{
CLIMATE CHANGE AND CITIES: A REVIEW ON THE IMPACTS AND POLICY RESPONSES
}

\author{
Osman BALABAN
}

Received: 29.01.2010, Final Text: 05.12.2011

Keywords: climate change; mitigation; adaptation; cities; policy responses and strategies.

\section{INTRODUCTION}

Climate change is one of the most important challenges of our time. It is likely to bring devastating impacts on human life and settlements. Climate change refers to changes in average climatic conditions of the earth due to the increase in average temperatures of the atmosphere (Figure 1). Although natural processes like solar activity and volcanic eruptions can cause changes in climatic conditions it is accepted that current climate change is caused by anthropogenic processes (Deri and Alam, 2008; IPCC, 2007a). There is a consensus that increased burning of fossil fuels and destruction of natural ecosystems, which were intensified after the industrial revolution (Figure 2), are major drivers of ongoing global warming and climate change (Costello et al., 2009).

Intergovernmental Panel on Climate Change (IPCC) explicitly proclaims that human-induced climate change is unequivocal and evident (Adger et al., 2003; IPCC, 2007a). This means, even the full implementation of most effective mitigation measures will not suffice to stop global warming and avoid climate change impacts (Klein et al., 2007). Therefore, along with mitigation actions to keep global warming and climate change at relatively lower levels, adaptation actions are also necessary to reduce vulnerabilities of human systems to climate change (IPCC 2007a). Mitigation actions are required to slow down the process of climate change and avoid further global warming by reducing the ongoing causes of climate change (Condon et al., 2009; Prasad et al., 2009). On the other hand, adaptation actions are vital to address unavoidable consequences of climate change in terms of pre-disaster and post-disaster vulnerabilities (Condon et al., 2009; Satterthwaite et al., 2007).

Cities can play crucial roles in tackling climate change by means of mitigation and adaptation actions. This is due to three fundamental reasons. First, cities contribute much to causes of climate change in terms of GHG emissions, land-use change and deforestation. It is estimated that 
Figure 1. Global Temperature Increase. Source: http: / / data.giss.nasa.gov/gistemp / graphs /
Figure 2. Global Anthropogenic Carbon Emissions. Source: Carbon Dioxide Information Analysis Center (CDIAC).

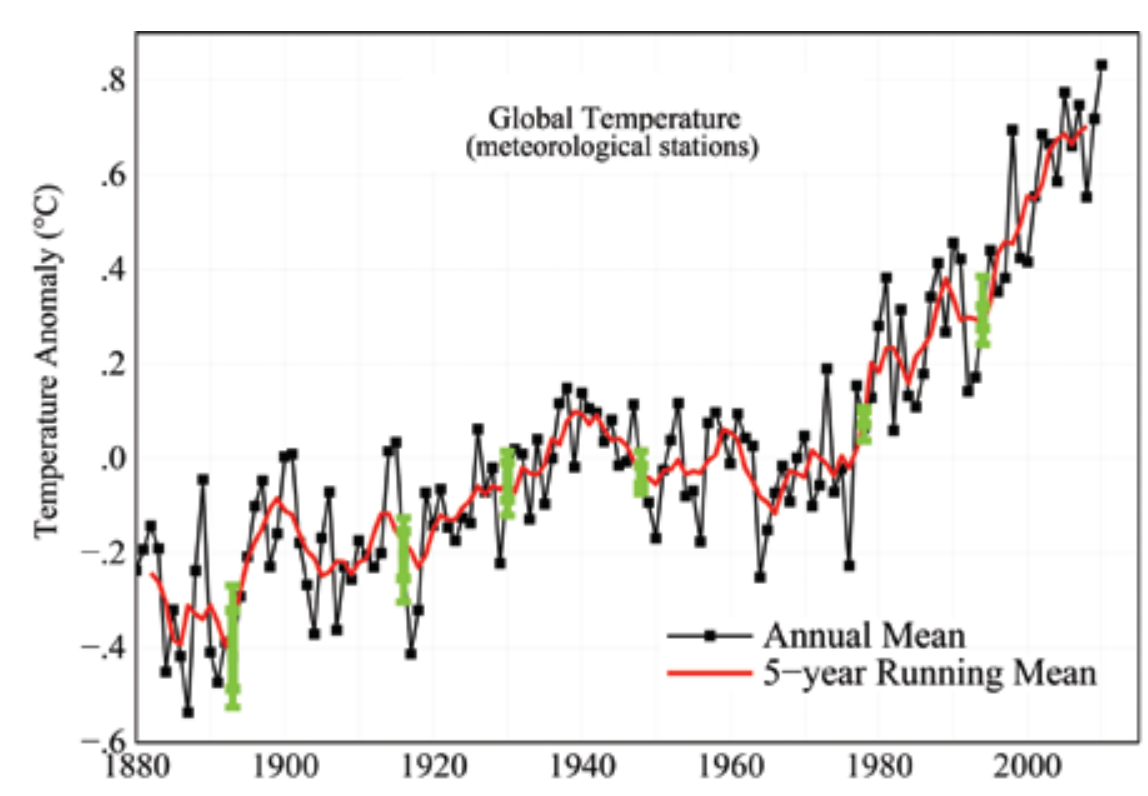

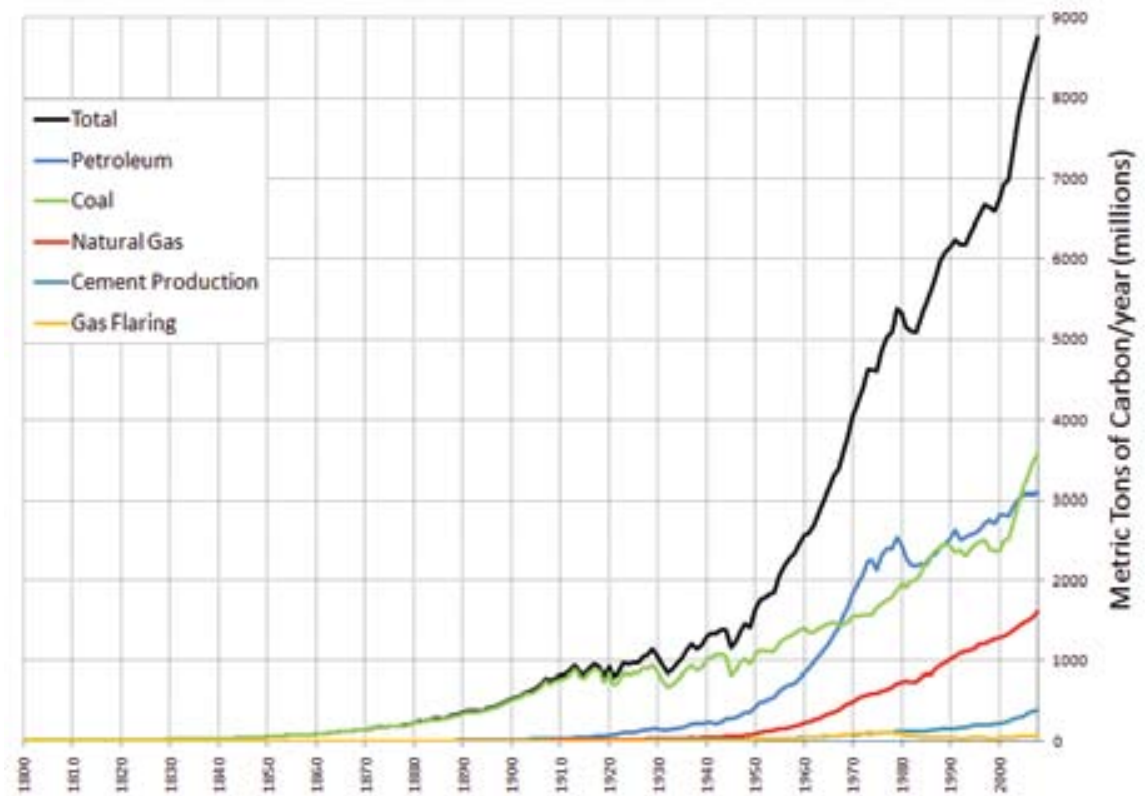

cities are responsible for $40 \%$ of all GHGs due to their $70 \%$ share in total fossil fuel combustion in the world (Dodman and Satterthwaite, 2009). Second, cities accommodate half of the world's population and most of its crucial economic activities. For instance, urban economic activities account for $55 \%$ of GNP in least developed countries, $73 \%$ in middle income countries, and 85\% in most developed countries (UN-Habitat, 2006). Climate change-related events will disturb the lives of a large part of the world's population and key economic activities. Conversely, despite being part of the problem, cities can also be an essential part of the solution. Inherent advantages of cities, such as concentration of people, enterprises and infrastructure, are, in fact, opportunities to formulate effective and low-cost solutions. Citywide actions offer greater capacity and economies 
1. For such policy responses, please see the following studies: Saavedra and Budd (2009); Dodman (2009); Puppim de Oliveira (2009); Jabeen et al. (2009); Condon et al. (2009); Satterthwaite (2008); Roberts (2008a); Roberts (2008b); Ewing et al. (2008); Satterthwaite et al. (2007); Gill et al. (2007); Alam and Rabbani (2007); Bulkeley (2006); Lee and Oh (2002). of scale in comparison to individual actions by households or enterprises (Satterthwaite et al., 2007).

Despite its importance, urban context has not been adequately addressed in climate change debates until recently. Agriculture and rural livelihoods were paid more attention in academic literature on mitigation and adaptation (Satterthwaite et al., 2007). Thus, it is not much to say that literature on climate change issues in urban context is an emerging one. However, a range of policy responses in terms of tangible strategies and actions to address climate change-related impacts were discussed and developed by various recent studies (1). Yet a systematic understanding of these policy responses has not been adequately developed. Broad and detailed expert reports aside, brief and urban context-related reviews on climate change are limited.

This paper aims to point to this gap and contribute to the emerging literature on climate change adaptation in urban context. Based on the review of major works in the field, this paper first provides an overview of most important impacts of climate change on cities, and then explores and discusses the policy responses, which are necessary for the transition from today's carbon-emitter and vulnerable cities to future's low-carbon and resilient cities.

\section{MAJOR IMPACTS OF CLIMATE CHANGE ON URBAN AREAS}

Climate change is now evident from observations of its various impacts in many parts of the world (IPCC, 2007a). For instance, 12 warmest years in last 150 years were recorded during the past 13 years and 1998 was found to be the warmest (Costello et al., 2009). Although it is not easy to predict with any precision all of the impacts of climate change several studies collate its potential and anticipated impacts (IPCC, 2001; Wilby, 2007; Hunt and Watkiss, 2007; Satterthwaite et al., 2007; Parry et al., 2007; Prasad et al., 2009). Among main impacts of climate change on urban areas are (a) rise in sea levels and storm surges, (b) extreme weather events and flooding, (c) heat waves and higher temperatures, (d) air pollution and reduced air quality, (e) water shortage and water pollution.

\section{Rise in Sea Levels and Storm Surges}

Climate change is likely to have potential impacts on coastal cities, particularly via rise in sea level and storm surges. IPCC predicts a rise of about $18 \mathrm{~cm}$ in sea levels by 2040 and about $48 \mathrm{~cm}$ by 2100 in the most extreme case (Prasad et al., 2009). Urban settlements that lie in deltas, low-lying coastal plains and islands are regarded as the most threatened coastal urban environments from sea-level rise (Hunt and Watkiss, 2007). Rise in sea levels and increase in frequency and intensity of storm surges are likely to have several consequences on coastal cities. The potential direct consequences include coastal flooding and inundation, displacement of populations, coastal erosion, receding coasts, and increased salinity in coastal aquifers (Satterthwaite et al., 2007; Hunt and Watkiss, 2007). However, potential indirect consequences include changes in functions of coastal ecosystems and reduction in coastal-based tourism activities (Hunt and Watkiss, 2007).

McGranahan et al. (2007) elaborate on the amount and proportion of people living along the coastal zone, which is at most risk from sea-level rise. As per their calculations (McGranahan, 2007), low-elevation coastal 
2. Low-elevation coastal zone is defined as "land area contiguous with the coastline up to a 10-metre rise elevation" in that study. zone, which covers $2 \%$ of the world's land area, accommodates $10 \%$ of the world's population and $13 \%$ of its urban population (2). China is the most populous country in this zone with approximately 145 million people. China is followed by India, Bangladesh, Vietnam, Indonesia and Japan. Furthermore, Bangladesh and Vietnam have almost half of their total population living in this zone (McGranahan et al., 2007). The six most populous countries in low-elevation coastal zone are in Asia, where Mumbai, Dhaka and Shanghai are cities that are at most risk (Satterthwaite et al., 2007).

\section{Extreme Weather Events and Flooding}

As widely accepted, climate change is likely to increase the frequency and intensity of floods mainly due to extreme weather events. Climate change is expected to increase flood risks in cities in three ways (Satterthwaite et al., 2007). First one is associated with precipitation changes, which bring rainfall more than historical records. Second, higher levels of the sea and storm surges will end up with coastal flooding. Finally, increased river flows due to glacial and snow melts may cause floods in urban areas. In this respect, more flooding is likely in wetter and warmer winters, as a result of more frequent rain and snow melting (Hunt and Watkiss, 2007).

Flood events already had very large impacts on urban settlements in many parts of the world. Serious floods of 2005 in Mumbai left over 1,000 people dead and caused massive damage to homes and livelihoods (Satterthwaite et al., 2007). A flash flood caused by a rainfall within historical records in Istanbul in 2009 brought 31 casualties and significant economic losses. However it is not possible to quantify the changes in flood risks with any precision for all urban areas (Wilby, 2007). This is because urban flood risks are not associated only with precipitation changes. Instead they emerge as a result of the interaction among precipitation changes and a range of spatial factors, such as number of population settled in flood-prone areas, capacities of urban drainage systems, and changes in land-use structure in and around watersheds (Hunt and Watkiss, 2007; Satterthwaite et al., 2007; Wilby, 2007).

\section{Heat Waves and Higher Temperatures}

Large cities with higher densities generally suffer from urban heat island effect, which means $5^{\circ} \mathrm{C}$ to $6^{\circ} \mathrm{C}$ higher temperatures in urban cores than surrounding rural areas (Wilby, 2007; Satterthwaite et al., 2007). Climate change is expected to increase the frequency and severity of urban heat island effects due to increased solar radiation and reduced wind speeds (Wilby, 2007). It is accepted that most cities will face more heat waves, higher temperatures and drought (Hunt and Watkiss, 2007; Satterthwaite et al, 2007; Wilby, 2007).

Heat waves and temperature increases may have several consequences on human life and urban economies. First of all, higher temperatures will increase energy demand for indoor cooling. For city of Athens, it is calculated that energy demand during summer time will increase $30 \%$ by 2080s (Giannakopoulos and Psiloglou, 2006). Such consequences would be more severe in hotter climate, where space cooling is already a major concern (Hunt and Watkiss, 2007). Second, heat waves and temperature increases are likely to affect human health in terms of increased heatrelated diseases and health problems and of higher rates of summer mortality (Satterthwaite et al., 2007; Wilby, 2007). Third, more frequent and intense heat-wave conditions may bring changes in existing tourism 
destinations and discourage travelers to go to certain regions like southern Europe during summer (Hunt and Watkiss, 2007). Furthermore, higher temperatures and heat waves will contribute to water stress due to increased water consumption in warmer periods, and cause degradation of urban greenery and ecosystems.

The heat wave caused by increased summer temperatures by $3^{\circ} \mathrm{C}$ to $5^{\circ} \mathrm{C}$ in 2003 has had significant consequences in southern and central Europe. Several countries including Belgium, UK, Germany, Italy, Spain and France were reported 35,000 deaths during heat wave period (Parry et al., 2007). Likewise, the heat wave in Andhra Pradesh (India) caused more than 1,000 deaths, most of which are laborers working outside in small towns (Satterthwaite et al., 2007).

\section{Air Pollution and Reduced Air Quality}

Deterioration of air quality or increase in air pollution is another likely consequence of climate change. As concentrations of air pollutants, such as photochemical smog and ozone precursor biogenic volatile organic compounds (VOCs) are linked to level of temperatures, solar radiation and humidity, air pollution may increase during heat waves (Wilby, 2007; Satterthwaite et al., 2007). Besides, less wind speed, which means less air circulation in and through urban areas in warmer periods, can contribute to worsening of air quality. Increased air pollution and reduced air quality are expected to bring about health problems like diseases related to respiratory system, such as asthma.

\section{Water Shortage and Water Pollution}

Climate change can potentially result in water stress due to reduction in freshwater availability. It is already projected that annual average river runoff and water availability will decrease by $10 \%$ to $30 \%$ over some dry regions, some of which are presently water-stressed areas (Satterthwaite et al., 2007). Another projection suggests that water scarcity due to future rainfall scenarios will threaten the Mediterranean, central and south America, and southern Africa (Wilby, 2007).

Climate change will affect water supplies in two ways. First of all, cities and their water catchment areas will get less precipitation. Hence, changes in precipitation regimes will bring about reductions in river flows and falling in groundwater tables (Satterthwaite et al., 2007). Besides, high temperatures will increase the rate of evaporation, and thereby decrease water supplies (Hunt and Watkiss, 2007). For instance, it is estimated that increased temperature in Mekong Region in Southeast Asia will increase evaporation and transpiration on Mekong River by 10-15\%, and affect water supply to cities that depend upon Mekong River (Prasad et al., 2009). Second, temperature increases and heat waves will increase demand for water and water consumption (Satterthwaite et al., 2007; Wilby, 2007). Therefore, current water supplies will be under explicit pressure from both source reductions and demand increases. Besides, climate change will also bring reductions in water quality. Lower river flows will reduce the level of dilution of uncontrolled discharge and increase saline intrusion in estuaries (Wilby, 2007; Hunt and Watkiss, 2007). 


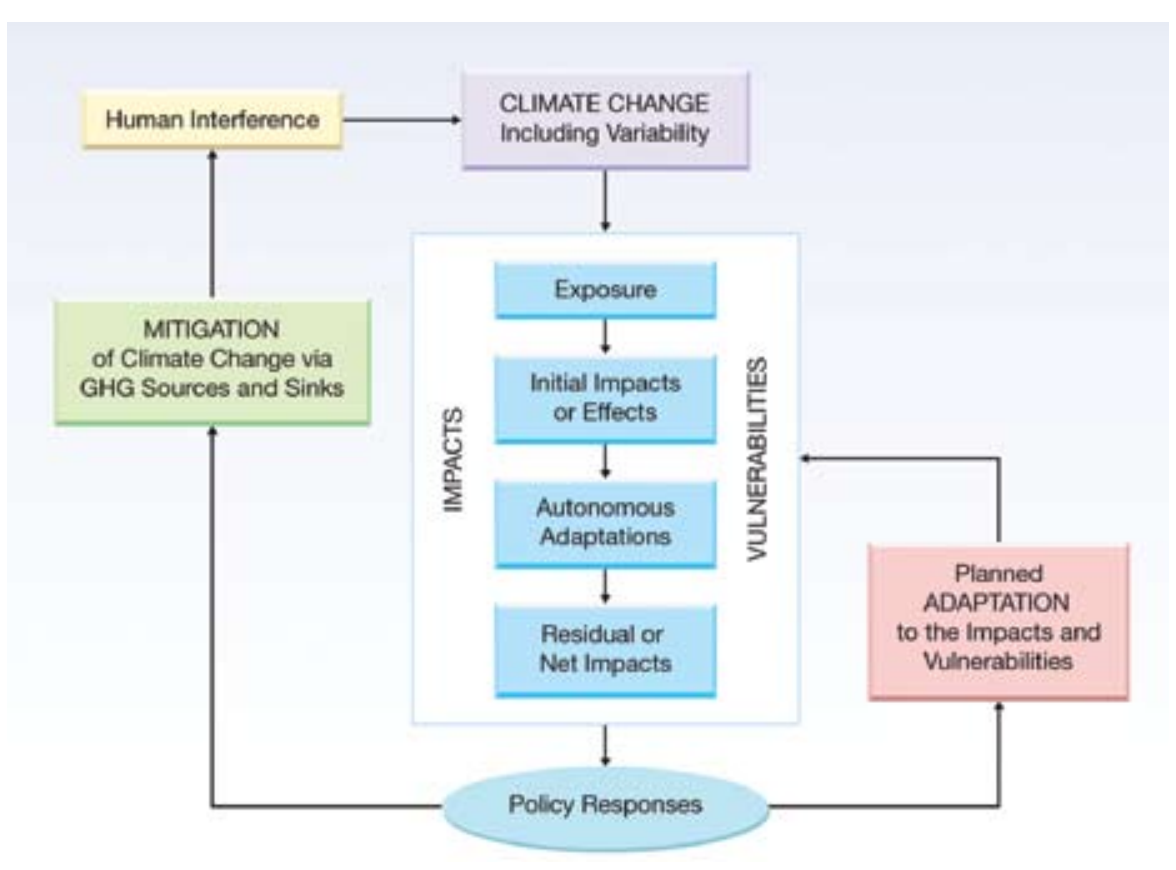

\section{POLICY RESPONSES TO TACKLE CLIMATE CHANGE AND ITS IMPACTS}

Appropriate policy responses can help cities and urban populations to tackle climate change, basically through enhancement of their mitigative and adaptive capacities (Figure 3). A range of policy responses is coming out of various recent academic and policy-oriented research, and being implemented in different cities across the globe. Policy responses that current literature provides can be grouped under three broad categories, namely political, sectoral and spatial. First of all, a group of policy responses are associated with political processes in cities, specifically with urban governance. Political policy responses refer to changes in decisionmaking and implementation processes as well as redistribution polices and mechanisms. Second, relevant policies in certain sectors like energy, transportation and construction could generate climate-positive outcomes, as these sectors are closely related to mitigation and adaptation. Last but not least, third group covers policy responses regarding spatial structures and elements in cities. Spatial policy responses cover a range of issues from regional scale to building scale.

\section{Political Policy Responses}

\section{a. Good Governance and Role of Local Governments}

Failures, limitations and bad practices at all levels of government play vital roles in creation of vulnerabilities to climate change in cities (Roberts, 2008a; Satterthwaite et al, 2007). Incapacity of local governments and reluctance of central governments to support policies at local levels make urban populations vulnerable to several climate change-related risks (Satterthwaite et al., 2007). Good governance in terms of integrating rights, norms and standards into policy-making and implementation is a key requirement for climate change mitigation and adaptation.

Satterthwaite (2006) emphasizes that climate change actions "will not be done by the market; it can only be done by governments". A significant 
part of the measures required to tackle climate problem is in form of public goods and services, which will be underprovided without government action (Satterthwaite et al., 2007). Besides, many climate change actions do not provide profits; instead they require additional spending or funding. In this sense, market mechanisms could bring about inadequate solutions and exclusive outcomes, especially for low-income groups (Satterthwaite et al., 2007). Thus, governmental bodies need to act more to fulfill the potential gap that will be left by the market. Therefore more government involvement is a necessity to achieve climate change-related goals.

As part of good governance practices, mechanisms for accountability and transparency at all levels of government need to be integrated into policymaking and implementation, especially in underdeveloped and developing countries, as they generally suffer from abuse of power and corruption. These political challenges prevent governmental institutions to address problems and put in place solutions effectively. Another likely outcome of abuse of power and corruption in these countries is inefficient use of limited resources.

Although actions at all levels of government are important local and sub-national governments have to play more crucial roles in climate change mitigation and adaptation (Condon et al., 2009; Jabeen et al., 2009; Puppim de Oliveira, 2009). Well-governed cities are known for their effective resilience and adaptive capacity as compared to badly governed cities. There are several reasons for the importance attributed to local governments and their associated actions and policies. First of all, local governments have a unique position to tackle the causes and effects of climate change due to their proximity to potential disaster areas and victims (Deri and Alam 2008, Puppim de Oliveira, 2009). Second, local governments can develop and implement regulatory frameworks and policies regarding land-use structures, infrastructure systems and building construction, all of which have significant influence on the extent of mitigation and adaptation capacities (Satterthwaite et al., 2007). Third, local governments, as the closest governmental level to citizens, have the opportunity to create more resilient societies not only by leading citizens but also by changing their attitudes on climate change-related risks (Deri and Alam, 2008). Fourth, city-wide actions that can be undertaken by local governments offer economies of scale as opposed to the individual actions by households and enterprises (Satterthwaite et al., 2007).

Based on a research in India, Revi (2008) emphasizes the importance of urban governance and strong institutional capacity at local level to address vulnerabilities to climate change-related risks. Likewise, the experiences in Durban (South Africa), which is known for its success in mainstreaming climate change issues in local political agenda, highlight the importance of capacity-building at local government level to tackle climate-related risks and develop adaptive responses (Roberts, 2008a).

However, positive progress in undertaking actions to tackle climate change at local level cannot be taken for granted, as local success requires certain conditions. Based on a research on 23 municipalities in the U.S., Kousky and Schneider (2003) point out that local governments tend to take action for climate change mitigation, only if they receive cost-savings and co-benefits. Likewise, support from upper levels of governance and international organizations is another essential requirement for local success. Without central governments' strong support in terms of sound political, legal and institutional framework and knowledge-base that 
facilitate decision-making and implementation process, progress by local governments at local level will be limited (Puppim de Oliveira, 2009; Corfee - Morlot et al., 2009).

\section{b. Integration of Policies and Awareness-Raising}

Policies responses to achieve climate change mitigation and adaptation are complex and multi-dimensional. In many cases, these policies are intersecting with other policy fields like disaster management, land-use planning, energy, transportation and construction sectors. Integration between climate change policies and other related policies is very important to achieve mitigation and adaptation goals effectively (Burton et al., 2002). The Case of Durban shows that once the local capacity to tackle climate problem is built, climate change policy should be mainstreamed into relevant local development plans and policies (Roberts, 2008a).

Likewise, based on empirical evidences from case studies in three countries, Puppim de Oliveira (2009) mentions that strong integration with related sectoral and governmental policies contributes to effectiveness of climate change policies at local level. The case of the German State of Saxony-Anhalt indicates that political will and effective policies at federal level stimulated local success and achievements (Puppim de Oliveira, 2009). Besides, the case of Sao Paolo (Brazil) highlights the role of synergies between climate change policies and other sectoral policies, such as pollution control (Puppim de Oliveira, 2009).

In addition to policy integration, effective community participation is key for tackling climate problem and increasing the resilience of urban communities. However participation depends upon awareness of climate problem among citizens and decision-makers. Kousky and Schneider (2003) claim that "awareness might just spur actions a few levels up", as they assume politically active citizens can influence policy makers to take necessary actions. Therefore, increasing the awareness of climate change impacts should be regarded as an essential component of climate policy. Local governments can benefit from education programs to raise awareness and provide citizens and local decision-makers with sufficient and updated information on climate change impacts. The initial phase of Municipality Climate Protection Programme in Durban aimed at understanding the range and extent of local impacts of climate change. Then, survey results on local impacts were used to raise awareness among professionals, stakeholders and policy-makers to engage them with climate change issues (Roberts, 2008a).

\section{c. Poverty Reduction}

Climate change is an uneven process. Its impacts will be more severe in cities of least developed and poor countries, where contribution to climate change is minimal (Figure 4) (Alam and Rabbani, 2007; Satterthwaite et al., 2007; Costello et al., 2009). Therefore, poverty reduction should be given high priority among policy responses that aim to adapt human settlements to climate change impacts (Costello et al., 2009). Poverty reduction in context of climate policy should not be understood only in economical terms at individual level. It needs to be underpinned by a spatial dimension at urban level. Improvements in housing and living conditions of urban poor as well as urban infrastructure should be regarded as parts of poverty reduction process.

Poverty reduction in spatial terms at urban level can reduce climatic vulnerabilities of urban poor and low-income groups, which mostly live 
Figure 4. Countries Ranking by Per Capita Fossil Fuel $\mathrm{CO}_{2}$ Emission Rates. Source: Carbon Dioxide Information Analysis Center (CDIAC).

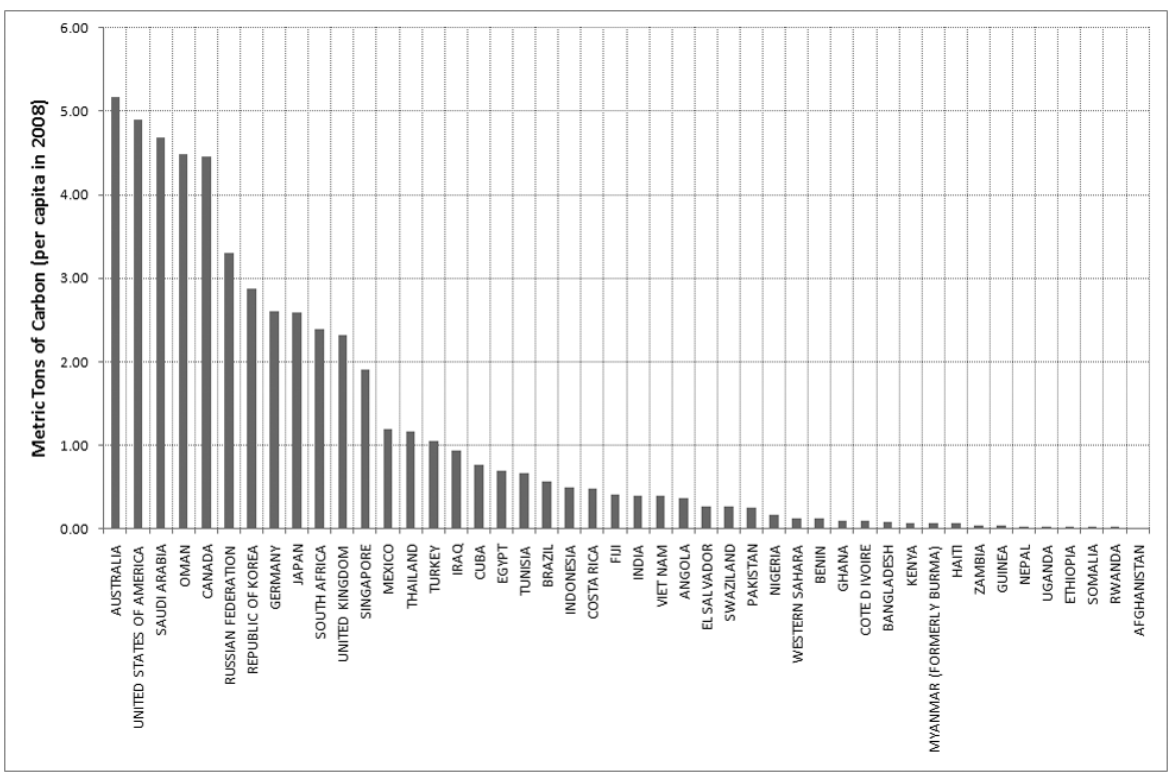

in dangerous locations and low-quality housing with almost no adequate infrastructure (Satterthwaite et al., 2007). Improvements in physical quality of urban settlements make cities and their poor inhabitants more resistant and resilient against climate change-related disasters (Costello et al., 2009). Likewise, poverty reduction in economical terms at household level increases the capacity and resources of households to adapt themselves to various consequences of climate change. Due to their limited resources, urban poor and low-income groups are not able to avoid direct or indirect impacts of climate change, for instance, by moving to good-quality houses or less dangerous places. Besides, they may not able to cope with various outcomes of climate change impacts like illness, injury, or loss of income (Satterthwaite et al., 2007). Another likely outcome of poverty reduction at individual level is the increase in awareness of climate change issues and community participation. It can be assumed that better off households will have more willingness to cooperate to reduce causes of climate change. Policy responses for poverty reduction should be based on a wide-ranging approach that ensures fair income distribution, increases in employment opportunities in cities, strengthens and diversifies urban economic structure, enhances abilities and qualifications of individuals.

\section{Sectoral Policy Responses}

\section{a. Energy Sector}

Energy sector is of crucial importance in climate change mitigation. The share of energy sector in total GHG emissions in world-wide is more than a quarter (IPCC, 2007b). To curb GHG emissions much could be expected from policy responses in energy sector. These policy responses should principally aim to reduce energy consumption, encourage energy-savings in industrial, commercial and residential sectors, and improve access to clean and renewable energy in affordable manners.

Puppim de Oliveira (2009) mentions energy-related measures and programs implemented in Mie Prefecture in Japan in order to mitigate climate change. The prefecture (3) introduced a series of policy responses to encourage industrial companies as well as public sector bodies and municipalities to reduce their energy consumption, and thereby reduce 
overall GHG emissions of the prefecture. Residents of the prefecture were given awards and benefits in case domestic electricity consumption is reduced. Likewise, the German State of Saxony-Anhalt is known for its performance on transition from traditional sources to renewable energy. Provision of economic incentives by federal government in terms of long term subsidies for renewable energy production resulted in restructuring of many energy plants to have them more energy-efficient and environmentally-friendly (Puppim de Oliveira, 2009).

Another interesting case in this respect is Korea, where government introduced various mitigation policies in energy sector. As of late 1990s, Korean government put in place policies to encourage the owners of energy-intensive large buildings to install energy saving facilities and households to use energy-efficient appliances (Lee and Oh, 2002). Experiences in Korea also highlight the importance of energy-pricing policies to control energy consumption, as it was observed that low energy prices result in overconsumption of energy and development of energyintensive land-uses (Lee and Oh, 2002).

\section{b. Transportation Sector}

Transportation sector is being given special attention within climate change policy, as the sector is an important emitter of GHGs, particularly $\mathrm{CO}_{2}$ emissions. IPCC (2007a) estimates that as of 2004, 13\% of total GHG emissions in terms of $\mathrm{CO}_{2}$ were from transportation sector. According to Ewing et al. (2008) a full third of $\mathrm{CO}_{2}$ emissions in the U.S. comes from transportation sector. The situation is quite similar in underdeveloped and developing countries. For instance, 17\% of GHG emissions, of which 70\% is from road transportation, in Bangladesh are from transportation sector (Alam and Rabbani, 2007). Likewise, land transportation is responsible for almost half of GHG emissions in Sao Paulo in Brazil (Puppim de Oliveira, 2009).

Several policy responses are being implemented by local and national governments in order to reduce emissions from transportation sector. It is being argued that reducing transportation-related $\mathrm{CO}_{2}$ emissions is a three dimensional process (Ewing et al., 2008). First and second dimensions are associated with vehicle fuel economy and carbon content of fuels used. Development of more efficient vehicles and lower-carbon fuels are the main policy options in this respect. Conversely, the third dimension is related to amount of distances driven by vehicles. While the first two dimensions are linked with technological improvements in vehicle and fuel production, the third dimension is explicitly related to urban development (Ewing et al., 2008).

The structural features of urban environments determine the extent of private traffic within that environment. A compact city with extensive and well-functioning public transportation can prevent heavy use of private cars. Whereas in sprawled cities, where density is low and distances between urban functions are high, car usage is the dominant mode, and extent of private traffic increases over time as opposed to public transportation ridership. Comparison between cities in the U.S. and in Europe and Asia, which differ structurally and spatially, provides significant evidences to this debate. According to Satterthwaite (2008), there are three to five times differences in gasoline use per capita between most U.S. and European cities and this is merely because European cities mostly have high-quality and efficient public transport systems as well 
as high-density downtowns with sufficient opportunities for walking and cycling. Vehicle use in U.S. cities is 7.5 times higher than in wealthy Asian cities, while vehicle ownership per capita is only 5 times higher in U.S. cities (Santos et al., 2010). This is also attributed to the automobiledependency and sprawled land-use patterns in U.S. cities.

Lee and Oh (2002) mentions that urban transportation policies have been an essential part of mitigation policies in Korea since late 1990s. Korean government encouraged the development and use of mass-transit systems rather than private cars in major urban centers, especially in Seoul. For instance, eight subway lines integrated with bus lines and bus-only lanes were built in Seoul to reduce private traffic and $\mathrm{CO}_{2}$ emissions driven by urban transportation (Lee and Oh, 2002). Furthermore, the government also introduced the 'fuel efficiency program' and its associated measures to promote production of fuel-efficient cars and use of cars with small engine capacity (Lee and Oh, 2002). A similar policy option was implemented in Mie Prefecture (Japan) as part of mitigation policies. The prefecture government introduced a policy to encourage use of low-emission cars in the entire metropolitan area (Puppim de Oliveira, 2009).

\section{c. Construction Sector}

Buildings are responsible for significant part of total energy consumption and GHG emissions, especially in cities of high income nations. Roberts (2008b) mentions that $45 \%$ of total energy consumption and associated emissions in the U.K. take place in buildings. However global figures regarding $\mathrm{CO}_{2}$ emissions from buildings are lower, as contribution of cities in low and middle-income countries to emissions is minimal. As of $2004,8 \%$ of the world's total GHG emissions were from commercial and residential buildings (IPCC, 2007b).

Considering high emissions from buildings, building design and construction methods need to be modified and linked with mitigation policies (Roberts, 2008b Wilby, 2007). Methods and outcomes of construction activity should be altered accordingly to satisfy a transition from traditional urban fabric to energy-efficient and environmentallyfriendly buildings (Costello et al., 2009). Several policy directions can be mentioned in this respect. First of all, new buildings should be designed in ways to resist natural disasters and constructed with strong structural components, especially in high risk zones (Roberts, 2008b). Second, energyefficient buildings, which consume less energy, should be built by means of thermal insulation, airtight construction details, high-performance windows, etc. (UNEP 2007 cited in Roberts, 2008b). Third, low-carbon materials should be used in building construction (Roberts, 2008b) and buildings should come with sustainable infrastructure utilities, such as green roofs and walls, rainwater storage system, etc. (Gill et al., 2007). Last but not least, renewable energy generation via solar panels and water heaters, wind turbine technology and biomass boilers should also be considered and applied to building designs and construction to reduce consumption of fossil-based energy (Roberts, 2008b).

\section{Spatial Policy Responses}

\section{a. Promoting Polycentric City Regions and Compact Urban Forms}

Perhaps the most important group of policy responses is the one regarding spatial structures and elements in cities. Spatial policy responses are critical to tackle climate change, as they have long-term and long-lasting effects. 
Besides, city governments can play an important role in decision-making to develop and introduce such policies. The discussion on spatial policy responses to mitigate and adapt to climate change impacts starts with spatial structures and built forms at regional and city scales. Promoting sustainable spatial forms at regional and urban levels, such as polycentric city-regions and compact cities are argued to be effective in achieving the goals for sustainability as well as mitigation and adaptation (Condon et al., 2009; Okabe, 2005; Ewing et al., 2008).

City-regions have two fundamental spatial structures, namely monocentric and polycentric (Kloosterman and Musterd, 2001). Monocentric cityregions (MCRs) are composed of a single metropolitan city and several dependent settlements in its suburbs, as opposed to polycentric cityregions (PCRs) that include several autonomous towns located close to each other (Kloosterman and Musterd, 2001; Okabe, 2005). Unlike the dependence of suburban settlements on core city in MCRs, there is no clear hegemony among key cities of a PCR (Kloostermann and Lambregts, 2001). Furthermore, PCRs are characterized by good public transportation systems in key cities and green space availability (including agricultural lands) between key cities (Kloosterman and Musterd, 2001). When patterns of living and working in PCRs are both considered, PCRs are argued to be more sustainable than MCRs (Okabe, 2005). Flexibility that polycentric model provides to its inhabitants in terms of including self-sufficient and high-density compact cities with high access to daily facilities and green spaces via public transport is regarded as an essential virtue for sustainability (Okabe, 2005). The potential virtues of PCRs for sustainability can also be considered as virtues for climate change mitigation and adaptation, as both environmental goals could be achieved through similar means.

Along with the debate on PCRs, compact cities and urban forms are also often argued whether such spatial forms are more sustainable and effective in mitigating and adapting to climate change impacts. The concept of 'compact cities' emerged in early-1990s, when the Green Paper on Urban Environment was published by the Commission of the European Community (Kaido, 2005). Compact city refers to an urban environment which is characterized by "higher average 'blended' densities", mix of land-uses, and an efficient public transportation system that also provides opportunities for non-motorized modes, such as walking and cycling (Ewing et al., 2008; Kaido, 2005). It is the increased accessibility due to juxtaposition of urban functions like residences and workplaces in a relatively smaller land area that makes compact cities more important and effective for climate change mitigation and adaptation.

Compact cities contribute climate change mitigation via reduced energy consumption for urban transportation. Urban density is an essential factor that affects the level of $\mathrm{CO}_{2}$ emissions driven by transportation activities. The most densely populated cities, generally located in developed nations, consume less energy for private passenger transportation, and thereby emit less GHG (Dodman, 2009). Figure 5 presents the relationship between urban density and transport-related energy consumption. As shown, in U.S. and Australian cities, where urban sprawl and lowdensity suburbanization is the norm, per capita energy consumption for transportation is higher. Compact urban forms are found to be effective in reducing car usage and thereby $\mathrm{CO}_{2}$ emissions, due to higher density urban environments they contain. Some research provided evidence 


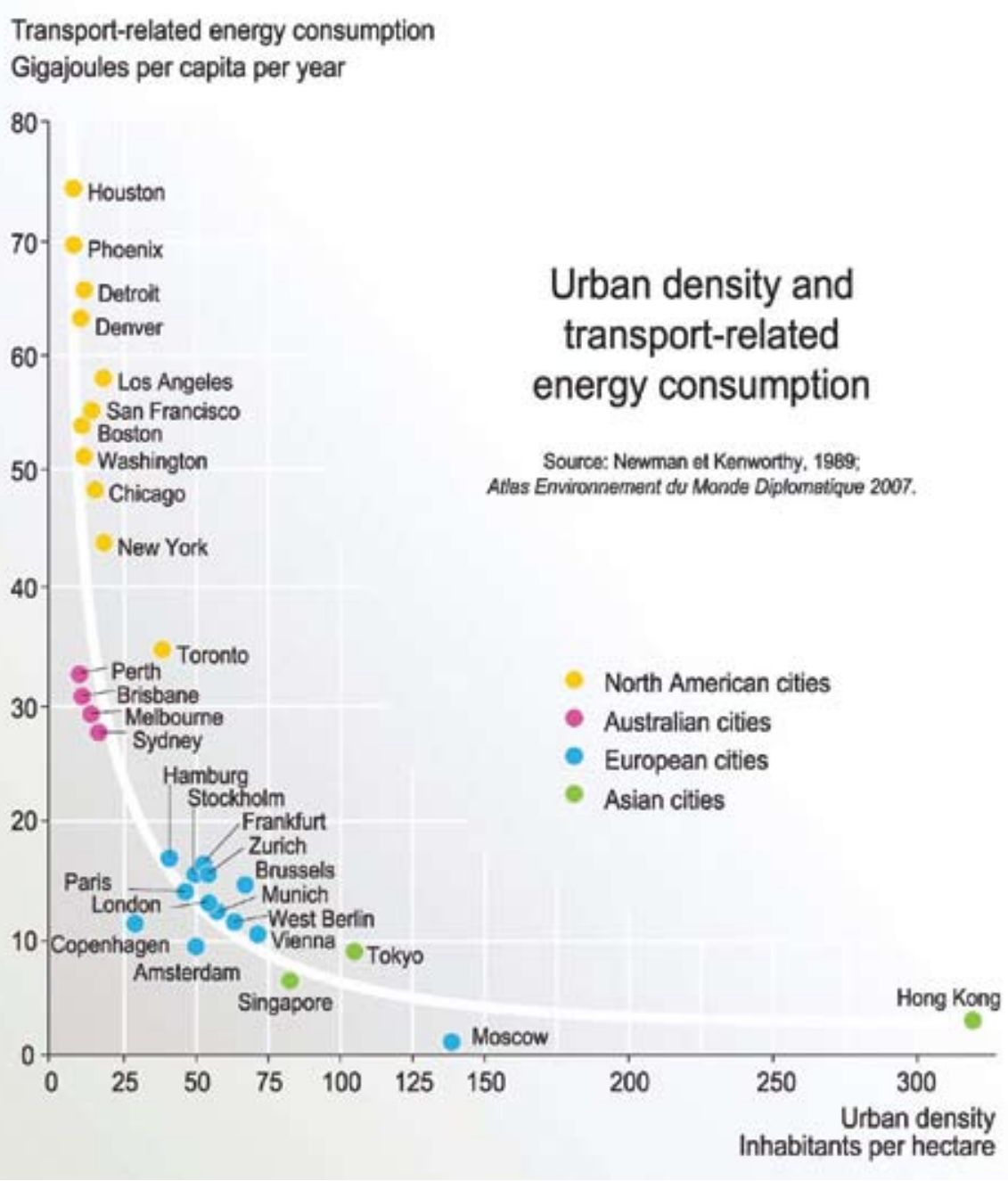

Figure 5. Urban Density and TransportRelated Energy consumption. Source: Suzuki et al., 2010. that show $20 \%$ to $40 \%$ reduction in miles driven by private cars is very likely with more compact development (Ewing et al., 2008). In Portland (US), for instance, per capita vehicle trips were decreased 17\% and GHG emissions were kept at levels of 1990 despite a 16\% growth in population by promoting compact urban growth since 1990 (Condon et al., 2009). Besides, a survey in Toronto (Canada) indicates that automobile emissions dominate total emissions, as distance from the central core increases (Dodman, 2009). Based on these evidences, it is widely accepted that policy options that reduce travel by limiting suburban expansion and encourage more compact development, where people live within walking or cycling distances of their daily destinations, can make a significant contribution to climate change mitigation (Condon et al., 2009; Ewing et al., 2008).

Benefits of compact urban development are not limited just to reduction in GHG emissions from transportation. Compact cities are also cost-effective and more efficient in terms of energy and resource used for infrastructure provision. Infrastructure costs and energy consumption are higher in sprawled cities, as $70 \%$ of cost of water supply systems goes for pipes, and $30 \%$ of urban energy consumption goes for pumping of water and collection of waste water (Suzuki et al., 2010). Furthermore, other climate change co-benefits of compact cities are preservation of agricultural lands 
and forests surrounding cities, and protection of water quantity and quality. In Utah (U.S.), compact urban growth is calculated to bring about 4.5 billion $\$$ savings in infrastructure spending, leave 171 square miles land unoccupied, and reduce per capita water use by more than 10\% (Ewing et al., 2008).

\section{b. Effective Use of Land-Use Planning and Development Controls}

Ljubljana Declaration on Urban Regeneration and Climate Change (EFAP, 2008) draws attention to the idea that urban planning together with architecture and construction management are of crucial important for climate change mitigation and adaptation. City governments can prevent developments in high-risk areas, support mitigation efforts and reduce climatic vulnerabilities of urban poor and collective infrastructure by means of land-use (urban) planning and development controls (Jabeen et al., 2009). Bulkeley (2006) mentions that most of the UK's GHG emissions are from domestic and transportation sectors within which spatial planning has a key role to play for emission reductions. Achievement of such goals through urban planning necessitates mainstreaming of climate change mitigation and adaptation goals into urban planning and management processes (Satterthwaite et al., 2007). The case of Durban clearly indicates how climate change concerns can influence strategic planning undertaken by city government. One of the positive outcomes of the "Municipal Climate Protection Programme" of City of Durban has been the recognition of climate change as a strategic issue to be addressed in local government's Integrated Development Plan (Roberts, 2008a).

Prior to any action concerning urban planning and management, existing risks and vulnerabilities in a local context have to be identified and mapped via most recent tools and techniques (Satterthwaite et al., 2007). Such identification of climatic vulnerabilities should be made in a comprehensive manner and constitute the initial step of an effective adaptation by means of land use planning and development controls (Burton et al., 2002). This is because potential success of future-oriented decisions depends upon accuracy and validity of information they are based on. Sherbinin et al. (2007) define the identification of climatic vulnerabilities of a locality as "vulnerability assessment", and mention that it should include identification of "which people and systems are vulnerable to what kind of climate hazards".

Following the identification of current vulnerabilities and likely local impacts, a holistic adaptation strategy (based on potential climate change impacts at local level) should be developed, as in the case of Durban. The adaptation strategy of City of Durban listed the likely climate change impacts on key sectors and outlined the necessary adaptation actions to reduce these impacts (Roberts, 2008a). Sherbinin et al. (2007) argue that adaptation strategy based on existing climatic vulnerabilities should contain "disaster preparedness and management plans" as complementary tools to other forms of planning at local level. By considering various hazards and risks along with climate concerns, adaptation strategy would not only help protecting urban settlements from climatic disasters like floods but also regulating hazardous activities that might originate from industry, energy plants, transport, etc. (Satterthwaite et al., 2007). Needles to say, actions outlined by the adaptation strategy should be coordinated and harmonized with land-use plans, development controls and standards on building design and construction. 
Nevertheless, existing urban planning and construction practices, in most cases, cannot be relied on, as they mostly ignore climate change issues and concerns. Therefore, a key step in mainstreaming climate change concerns into urban planning is reconsideration and revision of current planning frameworks and practices. Costello et al. (2009) underline the need for "better planning under climate change conditions" and renewal of land-use planning and building regulations. Revi (2008), based on Indian experience, points to the inadequacy of legislation concerning urban planning, urban development and infrastructure, and recommends renewing existing methods of preparation of urban development plans in order to make them harmonious with disaster management and climate change mitigation and adaptation.

\section{c. Role of Green and Blue Infrastructure}

Many studies emphasize the importance of green and blue infrastructure in cities to mitigate climate change and adapt to its impacts (Gill et al., 2007; Wilby, 2007; Yang et al., 2005; Novak and Crane, 2002). Green infrastructure in the form of forests, gardens, parks, productive landscapes, green corridors, green roofs and facades are known to be multi-functional and provide several benefits. First of all, green spaces, especially trees and soils can play a significant role in mitigating air pollution and sequestration of carbon (Yang et al., 2005; Novak and Crane, 2002). As green spaces provide cooler microclimates (Gill et al., 2007), they can reduce the concentration of temperature-dependent air pollutants along with direct absorption of gaseous pollutants by trees from the air (Yang et al., 2005). It is calculated that trees in central part of Beijing removed 1261.4 tons of pollutants from the air in 2002 (Yang et al., 2005). Likewise, a field research on 10 cities in the U.S. indicates that urban trees can store 700 million tons of carbon with a gross sequestration rate of 22,8 million tC/yr in U.S. (Novak and Crane, 2002). The Kyocera Group in Japan, a company specialized on green curtains, estimates that green curtains at their locations with a total length of $294 \mathrm{~m}$ and total area of $775 \mathrm{~m}^{2}$ absorb approximately $10,651 \mathrm{~kg}$ of $\mathrm{CO}_{2}$ (roughly similar to that of absorbed by 761 cedar trees) throughout their annual growth cycle (Doll and Balaban, 2011).

Furthermore, green spaces are also argued to be effective in mitigating UHI effect by reducing heat stress, and reducing flood risks by increasing rain water infiltration (Gill et al., 2007; Wilby, 2007; Hunt and Watkiss, 2007). The modelling that Gill et al. (2007) developed provides evidence to the role played by urban green spaces in moderating increases in summer temperatures and surface water runoffs. Adding $10 \%$ green in high-density residential areas and town centers are found to keep surface temperatures below most of the baseline levels estimated in climate change scenarios (Gill et al., 2007). Besides, they also concluded that greening the roofs in areas with high proportion of buildings is an effective strategy to keep surface temperatures below all baseline levels in scenarios (Gill et al., 2007). Conversely, the modeling indicates that use of green spaces on its own is less effective at moderating the volume of surface water runoff due to increased winter precipitation brought by climate change (Gill et al., 2007). Considering this result, authors recommend supporting the use of green spaces by increased storage of excess storm water via sustainable urban drainage (SUDS) techniques including swales, infiltration, detention and retention ponds in parks (Gill et al., 2007). Curitiba (Brazil) is an interesting example, where city government converted a former flooding zone into an urban park and lake to contain and control storm water flow, instead of an 
attempt to mitigate flood risk via structural measures (Suzuki et al., 2010). Besides, creation of blue infrastructure in cities can also help moderating temperature increases and heat waves, as water bodies and sustainable drainage systems provide evaporative cooling.

All in all, it can be concluded that provision of a network of green and blue spaces in cities can be an effective policy response to mitigate climate change as well as adapt to its adverse impacts. However, it should be noted that appropriate irrigation measures should be integrated into urban greening strategies to benefit from green and blue infrastructure in mitigation and adaptation. As climate change may result in water shortage, sustainable irrigation methods for urban greenery need to be put in place, such as rainwater harvesting, reuse of grey-waters and storage of floodwaters (Gill et al., 2007).

\section{d. New Forms of Urban Services and Infrastructure}

Transition from traditional forms of urban services to climate and environmentally-friendly forms is another orientation for policy-makers to tackle climate problem. In this sense, priority must be given to four policy fields; public transportation, energy generation, infrastructure management and solid waste management.

As discussed earlier, transportation is an important contributor to GHG emissions and hence a policy field, where appropriate policy responses can help reducing emissions significantly. Urban passenger transportation constitutes a major part of total transport activities and city governments can intervene in it to mitigate climate change. First of all, cities must be provided with efficient and affordable public transportation systems that also include non-motorized transport options. Besides, city governments have to undertake necessary actions and measures to increase public transportation ridership and encourage walking and cycling, as opposed to use of private cars. There is no doubt that public transport policy can play a key role in reducing $\mathrm{CO}_{2}$ emissions from passenger transport (Santos et al., 2010). In addition to demand reduction and modal shift, city governments can also pursue policies regarding fuel efficiency and change the fuel base of vehicles on traffic in order to achieve the transition to less-polluting and less-emitting fuels (Metz, 2010). For instance in Delhi (India), based on the decision of the Supreme Court, CNG was made compulsory fuel for all types of public transport vehicles including auto-rickshaws (Sidhartha, 2003).

A significant part of the world's total energy consumption takes place in cities, not only for industrial activities but also for domestic purposes, such as indoor lighting, heating and cooling. Cities are estimated to be responsible for $70 \%$ of fossil fuel combustion in worldwide (Dodman and Satterthwaite, 2009). Therefore, much can be expected from policy interventions in fields of renewable energy and energy-efficiency in cities. City governments must undertake actions to encourage generation and use of renewable energy as well as reduce energy consumption through appropriate efficiency measures. However, it has to be noted that energy sector is a crosscutting one, where success of policy interventions depends upon integration with policies in other sectors like transportation and construction.

Tackling climate change via policy responses in cities requires sufficient attention to be paid to improvements in urban infrastructure systems, as vulnerabilities in most cases are associated with lack of or deficiencies in 
4. Yokohama City Website: http://www. city.yokohama.lg.jp/seisaku/senryaku/en/ policies/waste/ these systems. Considering that climate change will increase the frequency and extent of extreme weather events and climatic disasters, existing infrastructure systems in almost all cities should be redesigned, renewed or if possible, retrofitted, as they may not suffice under climate change conditions (Mirza, 2007).

Methane $\left(\mathrm{CH}_{4}\right)$ is an important GHG, of which solid wastes and landfills are significant emitters. GHG emissions from solid wastes vary between cities (generally higher in cities of developing countries) due to differences in consumption patterns and waste management processes (Dodman, 2009). Effective solid waste management systems, which promote reducing and recycling of wastes and capturing of $\mathrm{CH}_{4}$ from landfills, are proved to reduce emissions and also generate co-benefits. A good example to this is the action plan, namely G30, developed and implemented by Yokohama city in Japan. The plan aims to reduce and recycle solid wastes as much as possible in citywide by means of awareness-raising and participation of citizens and business community (4). Between 2001 and 2007, waste generation was reduced by $38.7 \%$ (from 1.6 million to 1 million tons), despite population increase of 166,000 people, and waste reduction resulted in 840,000 tons of $\mathrm{CO}_{2}$ reduction, equivalent to that of absorbed by 60 million Japanese cedar trees in a year (Suzuki et al., 2010). Likewise, Sao Paulo City in Brazil has managed to reduce $\mathrm{CH}_{4}$ emissions by $11 \%$ as a result of its policy for composting domestic organic waste, and tree trimming and gardening waste (Puppim de Oliveira, 2009).

\section{e. Effective Use of Urban Regeneration Projects}

As argued in the previous sections, spatial policy responses are of critical importance to tackle the climate problem by increasing the resilience of human settlements. Introduction of spatial policy responses necessitates certain forms of intervention into current built-up areas and land-use elements in cities. In this sense, urban regeneration can be an opportunity to introduce spatial policy responses, as regeneration practices inherently comprise such interventions ranging from renewal to rehabilitation. This applies to both developed and developing countries. Existing buildings in cities of developed nations are among main contributors to GHG emissions due to high energy consumption for heating and cooling. For instance, $40 \%$ of $\mathrm{CO}_{2}$ emissions in Europe are driven by existing buildings (EFAP). Therefore, existing building stock can be retrofitted and overhauled to make them more energy-efficient through urban regeneration projects in developed nations. On the other hand, there is a dual spatial structure in cities of developing nations, where informal and formal settlements coexist. The informal parts of such cities are generally known to be prone and vulnerable to several risks and hazards including the climatic ones. Regeneration projects can help city governments in developing nations to renew, rehabilitate or redevelop informal sections of their cities to make them more resistant and resilient. Besides, urban regeneration can also be used to achieve compact urban forms by concentrating new developments within current built-up areas of cities in both developed and developing nations (Couch and Dennemann, 2000). Ljubljana Declaration draws attention to control urban sprawl and recommends administrative authorities in EU to focus on urban regeneration to upgrade the existing physical environment (EFAP, 2008). Furthermore, urban regeneration projects can also offer opportunities to enhance green cover or provide additional green spaces in cities. All in all, urban regeneration policy can be regarded as a policy option to mitigate and adapt to climate change 
through rehabilitation, recycling and renewal of existing building stock and infrastructure utilities, and of underutilized lands.

There are recent examples of climate-friendly urban regeneration projects that reveal how urban regeneration contributes to mitigation and adaptation, especially in Northern European countries. Stockholm (Sweden) is transforming an old inner-city industrial area, namely Hammarby Sjostad, into an ecologically sustainable and climate-friendly urban district through an urban regeneration project (Suzuki et al., 2010). This project is part of a series of regeneration and redevelopment projects in central Stockholm. Hammarby project aims to utilize brownfields more efficiently by converting them into a mixed-use neighborhood, which is energy and resource-efficient, well connected to public transportation system and encourages people to walk and cycle (Suzuki et al., 2010). Although the project is not completed, some of the initial results reveal that non-renewable energy use, water consumption and global warming potential have been reduced $28 \%, 41 \%$ and $29 \%$ at minimum respectively (Suzuki et al., 2010).

\section{CONCLUSION}

Future urban growth has to be climate-friendly and resilient. GHG emissions have to be reduced and urban infrastructure and built stock have to be strengthened to resist climate change impacts. Only then, transition from carbon-emitter and vulnerable cities to low-carbon and resilient cities can be achieved. A broad range of urban policy responses are required to make such transition happen.

A group of climate change policy responses should address political and governance-related challenges in cities. Failures and limitations at all levels of governance that play vital roles in creation of climatic vulnerabilities should be eliminated by incorporating principles of good governance into policy-making and implementation. Local governments, which have unique position to tackle causes and effects of climate change, have to be empowered and given more responsibility. Besides, considering that climate change will affect the poor most, urban poverty has to be reduced and living conditions of urban poor have to be improved through fair redistribution policies and increased employment opportunities. Awareness-raising and community participation are the other key policy directions that can contribute to mitigation and adaptation.

The second group of policy responses is associated with certain sectors that are known to be critical to tackle climate change. In other words, relevant policies in energy, transportation and construction sectors could bring climate-positive outcomes in cities. Energy-related policies should target reducing energy consumption and improving access to renewable energy in cities. In the same manner, through effective urban transportation policies, such as use of more energy-efficient vehicles and increase in public transportation ridership, energy consumption from urban passenger transportation can be lowered. Besides, building construction with strong structural components, low-carbon materials and sustainable utilities are known to resist extreme events and consume less energy, thereby help mitigating climate change.

As per the classification in this paper, the last but not the least group of policy responses consists of strategies and actions regarding spatial structures and elements in cities. Promoting sustainable spatial forms at 
regional and urban levels, such as polycentric city-regions and compact cities are regarded to provide essential virtues for mitigation and adaptation. Likewise, provision of more green and blue infrastructure in cities provides multiple climate benefits including reduction of heat stress and flood risks as well as improving of air quality. Furthermore, retrofitting and rehabilitation of existing building stock and construction of climate-friendly buildings strengthen the built stock against extreme events and reduce energy consumption in buildings. In a similar manner, renewal and rehabilitation of infrastructure systems make them resistant against extreme events and bring about efficiency in resource use. However, introduction of spatial policy responses necessitates certain forms of interventions in current built-up areas in cities. Urban regeneration can be an opportunity in this respect, as regeneration practices inherently comprise such interventions ranging from renewal to rehabilitation.

As many countries in the world, Turkey is not immune from climate change impacts. It is already possible to observe certain impacts, such as changes in precipitation regimes, increase in floods, high temperatures, extended summers. Sufficient attention by researchers, academics and public policy-makers should be paid to prepare Turkish cities for the impacts of climate change. Yet, what has been done so far in this respect seems inadequate. Besides, some actions that are contradictory to climate change mitigation and adaptation objectives have been decided to be undertaken by national and local governments, as in the examples of 'sale of 2B lands' and 'construction of the third bridge over Bosporus' (Balaban, 2010). There are some major fields and issues in urban policy, where policy interventions are required to mitigate and adapt to climate change in Turkish cities.

Perhaps the first issue to mention is the climatic vulnerabilities of Turkish cities caused by the dual spatial structure that exist in almost every city in Turkey. Informal settlements in Turkish cities, most of which are located in high-risk areas, such as floodplains are vulnerable to many hazards including the climatic ones like extreme weather events. Besides, lowquality buildings, both formally and informally built, are also under threat from climate change impacts. So, spatial structure and elements in Turkish cities need to be rehabilitated and renewed so as to make them more resistant and resilient against climate change. Urban regeneration projects can be an opportunity here, as such projects help improving the spatial structure in current built-up areas, only if they are properly developed and implemented.

Urban passenger transportation constitutes another issue to deal with in Turkish cities when climate change is taken into consideration. In almost all of the metropolitan cities in Turkey, urban passenger transportation is road-based and car-reliant. Public transportation systems, especially mass rapid transit systems are not well-developed and non-motorized transportation almost doesn't exit. Given this situation, it is not much to think that urban transportation is among the most important GHG emitters in Turkey. Therefore, attention has to be given to improve public transportation infrastructure in cities and encourage people to use public and non-motorized transportation modes.

It is well-known and widely accepted that Turkish cities suffer from lack of sufficient green and open spaces. This is because green and open spaces are usually under development pressure and public bodies, in most cases, don't hesitate to allow urban development on greenfields. Green space 
availability within built-up areas in many Turkish cities is not adequate, and this can intensify climate change impacts in future. A major field of policy intervention regarding climate-friendly urban development in Turkey is therefore green space planning.

Above all, awareness of climate change issues among urban inhabitants, and policy and decision-makers is low in Turkey. There is a weak demand from citizens to push environmental agenda forward in cities. This results in reluctance and ignorance of politicians at national and local levels to take actions to tackle climate problem. In order to overcome this problem, researchers and academics, especially the ones working on urbanization issues should pay more attention to climate change debate and provide community with updated and accurate information on climate change and its associated local impacts.

\section{ACKNOWLEDGEMENTS}

The author is grateful to the United Nations University Institute of Advanced Studies (UNUIAS) and The Scientific and Technological Research Council of Turkey (TUBITAK) for supporting his postdoctoral studies through their fellowship programmes. The author also wishes to thank the editor and the reviewers for their constructive comments.

\section{SYMBOLS AND ABBREVIATIONS}

IPCC: Intergovernmental Panel on Climate Change

GHGs: Greenhouse Gases

US: United States of America

UK: United Kingdom

UN: United Nations

UNEP: United Nations Environment Program

PCRs: Polycentric City-Regions

MCRs: Monocentric City-Regions

EFAP: European Forum for Architectural Policies

EU: European Union

CNG: Compressed Natural Gas

$\mathrm{CO}_{2}$ : Carbon dioxide

$\mathrm{CH}_{4}$ : Methane

\section{REFERENCES}

ADGER, W. N., HUQ, S., BROWN, K., CONWAY, D., HULME, M. (2003) Adaptation to Climate Change in the Developing World, Progress in Development Studies, 3 (3); 179-95.

ALAM, M., RABBANI, M. D. G. (2007) Vulnerabilities and Responses to Climate Change for Dhaka, Environment \& Urbanization, 19 (1); 81-97.

BALABAN, O. (2010) İklim Değişikliği ile Mücadelede Kamu Sektörünün Rolü: Türkiye Üzerine Bir İnceleme, Amme Idaresi Dergisi, 43 (3); 83108.

BULKELEY, H. (2006) A Changing Climate for Spatial Planning, Planning Theory and Practice, 7(2); 203-14.

BURTON, I., HUQ, S., LIM, B., PILIFOSOVA, O., SCHIPPER, E. L. (2002) From Impacts Assessment to Adaptation Priorities: The Shaping of Adaptation Policy, Climate Policy, 2; 145- 59.

CONDON, P. M., DUNCAN, C., MILLER, N. (2009) Urban Planning Tools for Climate Change Mitigation, Policy Focus Report Series, Lincoln Institute of Land Policy, Cambridge, USA. 
CORFEE-MORLOT, J., KAMAL-CHAOUI, L., DONOVAN, M.G., COCHRAN, I., ROBERT, A., TEASDALE, P.J. (2009) Cities, Climate Change and Multilevel Governance, OECD Environmental Working Paper No: 14, OECD Publishing, OECD.

COSTELLO ET AL. (2009) Managing the Health Effects of Climate Change, Lancet and University College London Institute for Global Health Commission Report, v: 373, May 16, UCL, London, UK; 1693-733.

COUCH, C., DENNEMANN, A. (2000) Urban Regeneration and Sustainable Development in Britain: The Example of the Liverpool Ropewalks Partnership, Cities, 17 (2); 137-47.

DERI, A., ALAM, M. (2008) Local Governments and Climate Change, Commonwealth Secretariat Discussion Paper: One Pager, n:2, London, UK.

DODMAN, D. (2009) Blaming Cities for Climate Change? An Analysis of Urban Greenhouse Gas Emissions Inventories, Environment $\mathcal{E}$ Urbanization, 21 (1); 185-201.

DODMAN, D., SATTERTHWAITE, D. (2009) Are Cities Really to Blame, Urban World, 1 (2); 12-3.

DOLL, C., BALABAN, O. (2011) Urban Development with Co-Benefits: A Project of the United Nations University Institute of Advanced Studies, CONTACT Australasia, n: 21, September 2011; 18-22.

EFAP (2008) Ljubljana Declaration on Urban Regeneration and Climate Change, European Forum for Architectural Policies-EFAP (www.efap-fepa. eu).

EWING, R., KEITH, B., STEVE, W., JERRY, W., DON, C. (2008) Growing Cooler: The Evidence on Urban Development and Climate Change, Washington, DC: Urban Land Institute, Smart Growth America, Center for Clean Air Policy, and National Center for Smart Growth Education and Research.

GIANNAKOPOULOS, C., PSILOGLOU, B.E. (2006) Trends in Energy Load Demand for Athens, Greece: Weather and Non-Weather Related Factors, Climate Research, 31; 97-108.

GILL, S.E., HANDLEY, J.F., ENNOS, A.R., PAULEIT, S. (2007) Adapting Cities for Climate Change: The Role of the Green Infrastructure, Built Environment, 33 (1); 115-33.

HUNT, A., WATKISS, P. (2007) Literature Review on Climate Change Impacts on Urban City Centres: Initial Findings, Working Party on Global and Structural Policies, ENV / EPOC / GSP(2007) 10/FINAL, OECD, France.

IPCC (2007a) In Core Writing Team, Pachauri, R.K and Reisinger, A. (eds.), Climate Change 2007: Synthesis Report, Contribution of Working Groups I, II and III to the Fourth Assessment Report of the Intergovernmental Panel on Climate Change. IPCC: Geneva, Switzerland.

IPCC (2007b) Summary for Policymakers, in Metz, B., Davidson, O.R., Bosch, P.R., Dave, R. and Meyer, L.A. (eds.), Climate Change 2007: Mitigation, Contribution of Working Group III to the Fourth Assessment Report of the Intergovernmental Panel on Climate Change, Cambridge University Press, Cambridge. 
IPCC (2001) Climate Change 2001: The Scientific Basis, Contribution of Working Group I to the Third Assessment Report of the Intergovernmental Panel on Climate Change, Cambridge: Cambridge University Press.

JABEEN, H., ALLEN, A., JOHNSON, C. (2009) Built-In Resilience: Learning From Grassroots Coping Strategies To Climate Variability, Cities and Climate Change: Responding to an Urgent Agenda, Fifth Urban Research Symposium 2009, June 28-30 2009, Marseille: France; 1-19.

KAIDO, K. (2005) Urban Densities, Quality of Life and Local Facility Accessibility in Principal Japanese Cities, In Jenks, M. and Dempsey, N., (eds.), Future Forms and Design for Sustainable Cities, Great Britain: Elsevier; 311-37.

KLEIN, R.J.T., HUQ, S., DENTON, F., DOWNING, T.E., RICHELS, R.G., ROBINSON, J.B. and TOTH, F.L. (2007) Inter-relationships between Adaptation and Mitigation, In Parry, M.L., Canziani, O.F., Palutikof, J.P., Van der Linden, P.J. and Hanson, C.E., (eds.), Climate Change 2007: Impacts, Adaptation and Vulnerability, Contribution of Working Group II to the Fourth Assessment Report of the Intergovernmental Panel on Climate Change, Cambridge, UK: Cambridge University Press; 74577.

KLOOSTERMANN, R. C., LAMBREGTS, B. (2001) Clustering of Economic Activities in Polycentric Urban Regions: The Case of Randstad, Urban Studies, 38 (4); 717-32.

KLOOSTERMANN, R. C., MUSTERD, S. (2001) The Polycentric Urban Region: Towards a Research Agenda, Urban Studies, 38 (4); 623-33.

KOUSKY, C., SCHNEIDER, S. H. (2003) Global Climate Policy: Will Cities Lead the Way? Climate Policy, 3; 359-72.

LEE, H., OH, J. G. (2002) Mitigation Initiatives: Korea's Experiences, Climate Policy, 2, 197-209.

MCGRANAHAN, G., DEBORAH B., BRIDGET, A. (2007) The Rising Tide: Assessing the Risks of Climate Change and Human Settlements in Low-Elevation Coastal Zones, Environment and Urbanization, 19 (1); 17-37.

METZ, B. (2010) Controlling Climate Change, Cambridge University Press, UK.

MIRZA, M. (2007) Adaptation Options for the Built Environment: Linking Experiences of Developed and Developing Countries, IHDP Update, Issue 2, September 2007; 17-8.

NOWAK, D.J., CRANE, D.E. (2002) Carbon Storage and Sequestration by Urban Trees in the USA, Environmental Pollution, 116; 381-9

OKABE, A. (2005) Towards the Spatial Sustainability of City-Regions: A Comparative Study of Tokyo and Ranstad, In Jenks, M. and Dempsey, N., (eds.), Future Forms and Design for Sustainable Cities, Great Britain: Elsevier; 55-72.

PARRY, M. L., CANZIANI, O. F., PALUTIKOF, J. P., VAN DER LINDEN, P. J., HANSON, C. E. (eds) (2007) Cross-Chapter Case Studies, In Climate Change 2007: Impacts, Adaptation and Vulnerability, Contribution of Working Group II to the Fourth Assessment Report 
of the Intergovernmental Panel on Climate Change, Cambridge University Press, UK; 843-68.

PRASAD, N., RANGHIERI, F., SHAH, F., TROHANIS, Z., KESSLER, E., SINHA, R. (2009) Climate Resilient Cities: A Primer on Reducing Vulnerabilities to Disasters, World Bank, Washington DC.

PUPPIM DE OLIVEIRA, J. A. (2009) The Implementation of Climate Change Related Policies at the Subnational Level: An Analysis of Three Countries, Habitat International 33 (2009) 253-9.

REVI, A. (2008) A Climate Change Mitigation and Adaptation Agenda for Cities in India, Environment and Urbanization, 20 (1); 207-29.

ROBERTS, D. (2008a) Thinking Globally, Acting Locally-Institutionalizing Climate Change at the Local Government Level in Durban, South Africa, Environment and Urbanization, 20 (2); 521-37.

ROBERTS, S. (2008b) Effects of Climate Change on the Built Environment, Energy Policy, 36; 4552-7.

SAAVEDRA, C., BUDD, W. W. (2009) Climate Change and Environmental Planning: Working to Build Community Resilience and Adaptive Capacity in Washington State, USA, Habitat International, 33; 246-52.

SANTOS, G., BEHRENDT, H., TEYTELBOYM, A. (2010) Part II: Policy Instruments for Sustainable Road Transport, Research in Transportation Economics, 28; 46-91.

SATTERTHWAITE, D. (2008) Cities' Contribution to Global Warming: Notes on the Allocation of Greenhouse Gas Emissions, Environment and Urbanization, 20(2); 539-49.

SATTERTHWAITE, D. (2006) Climate Change and Cities, Sustainable Development Opinion, International Institute for Environment and Development (IIED), London, UK.

SATTERTHWAITE, D., HUQ, S., REID, H., PELLING, M., ROMERO LANKAO, P. (2007) Adapting to Climate Change in Urban Areas: The Possibilities and Constraints in Low- and MiddleIncome Nations, Human Settlements Discussion Paper Series: Climate Change and Cities 1, International Institute for Environment and Development (IIED), London.

SHERBININ, A., SCHILLER, A., PULSIPHER, A. (2007), Three Cities and Their Vulnerabilities to Climate Hazards, IHDP Update, n: 2, September 2007; 5-8.

SIDHARTHA, P. G. (2003) Present Scenario of Air Quality in Delhi: A Case Study of CNG Implementation, Atmospheric Environment, 37, 5423-5431.

SUZUKI, H., DASTUR, A., MOFFATT, S., YABUKI, N., MARUYAMA, H. (2010) Eco2 Cities: Ecological Cities as Economic Cities, The World Bank: Washington DC.

UN-HABITAT (2006) State of the World's Cities 2006/2007, Earthscan.

UNEP (2007) Buildings and Climate Change: Status, Challenges and Opportunities, United Nations Environment Programme.

UNEP (2005) Vital Climate Change Graphics, UNEP/ GRID-Arendal Publication. 
WILBY, R.L. (2007) A Review of Climate Change Impacts on the Built Environment, Built Environment, v: 33, n: 1; 31-45.

YANG, J., MCBRIDE, J., ZHOU, J., SUN, Z. (2005), The Urban Forest in Beijing and its Role in Air Pollution Reduction, Urban Forestry $\mathcal{E}$ Urban Greening, 3; 65-78.

Alındı: 29.01.2010, Son Metin: 05.12.2011

Anahtar Sözcükler: iklim değişikliği; azaltma; uyum gösterme; kentler; politika seçenekleri ve stratejiler.

\section{İKLIMM DEĞİŞIKLIIĞİ VE KENTLER: ETKİLER VE POLİTIKA FARKLILIKLARI KONUSUNDA BİR YORUM}

İklim değişikliği çağımızın en önemli küresel sorunlarından birisidir. İnsan yaşamı ve yerleşmeleri üzerinde çok önemli etkiler yapacağı bilinmekte ve beklenmektedir. Yakın bir zamana kadar iklim değişikliği alanındaki çalışmalar, iklim değişikliğine bağlı etkilerin tespit edilmesi ve küresel ısınma ile iklim değişikliğinin azaltılması (climate change mitigation) üzerine odaklanmaktaydı. Ne var ki, iklim değişikliğinin somut sonuçlarının gözlenmeye başlaması bu alandaki çalışmaların çeşitlenmesine yol açmıştır. Son zamanlarda azaltma (mitigation) amaçlı çalışmalar yanı sıra, iklim değişikliğinin yaratacağı olumsuz sonuçlara karşı önlem alınması ve oluşacak yeni durumlara uyum sağlanması (climate change adaptation) amaçlı çalışmalar da ön plana çıkmaya başlamıştır.

Kentler, iklim değişikliğinin azaltılması ve olumsuz etkilerine uyum sağlanması amaçlı çalışmalar bağlamında anahtar role sahiptirler. Öncelikle kentler, sera gazı emisyonlarını arttıran çeşitli işlevleri barındırmaları ve ormansızlaşma gibi arazi kullanım değişikliğine yol açmaları nedeniyle küresel ısınmanın ve iklim değişikliğinin varlık nedenleri arasındadırlar. Ayrıca dünya nüfusunun yarısı ile ekonomik kaynaklarının çok büyük bir bölümü kentlerde yer aldığından, iklim değiş̧ikliği, ekonomik ve demografik olarak dünyayı en çok kentler üzerinden etkileyecektir. Bu nedenle, bugün birçok araştırmacı, akademisyen ve politika-yapıcı azaltma (mitigation) ve uyum gösterme (adaptation) çalışmaları kapsamında kentlere özel önem atfetmektedirler. Giderek artan bu öneme rağmen, iklim değişikliğine uyum gösterme ve kentler (climate change adaptation and cities) konusundaki çalışmalar halen oldukça sınırlıdır. İklim politikası ile kentsel politikaların birbirine nasıl entegre edileceği ve kentleri iklim-dostu hale getirmek için nelerin yapılması gerektiği belirsizliğini korumaktadır. Bu alanda göze çarpan bir diğer eksiklik ise; azaltma ve uyum gösterme amaçlı politika seçenekleri ile stratejilere dair sistematik kavramlaştırma ve derleme çalışmalarının (uluslararası kuruluşlar tarafından hazırlatılan hacimli raporlar bir yana bırakılırsa), özellikle kentsel düzey ile ilişkili olarak yeterince üretilmemiş olmasıdır. Bu makalenin amacı, bu eksiklikten hareketle iklim değişikliğinin kentlerdeki olası etkileri ile bu etkileri en aza indirmek ve bunlara uyum göstermek için yapılması gerekenleri sistematik bir biçimde tartışmaktır. Türkiye' de iklim değişikliği ve kentler konusundaki çalışmaların henüz istenen düzeye erişmedikleri de dikkate alındığında, yeni bazı çalışmaların tetiklenmesi de bu makalenin dolaylı hedefleri arasinda yer almaktadır.

OSMAN BALABAN; B.CP., M.Sc. in Urban Policy Planning, Ph.D.

Graduated from the Department of City and Regional Planning at METU (1996); received his MSc from Urban Policy Planning and Local Governments Program at METU (2000); earned his PhD Degree from the Department of CRP at METU (2008). Currently works as a postdoctoral research fellow at United Nations University, Institute of Advanced Studies in Japan. Research interests include urban planning, urban politics, local governments and climate change mitigation and adaptation. 